\title{
Triple Oxygen isotope clue of enigmatic nodular chert formation in Vindhyan carbonates and an insight into the late Neo-Proterozoic seawater composition
}

\author{
S. GHOSHMAULIK ${ }^{1, *}$, S.K. BHATTACHARYA ${ }^{1}$, A \\ SARKAR $^{1}$, P.ROY $^{1}$ \\ ${ }^{1}$ Dept. of Geology and Geophysics, IIT Kharagpur, India- \\ 721302,*ghoshsangbaran@gmail.com
}

Limestone hosted nodular cherts form by replacement of carbonate by siliceous fluids. The source of this fluid varies widely- from hypersaline water, marine water, meteoric water or hydrothermal fluid. Identifying the source of the fluid can throw light on the diagenetic conditions during the chert formation. The Proterozoic Bhander limestone from the Vindhyan Basin, India host number of such bedded chert nodules. Previous petrographic studies indicated that these silica nodules formed by carbonate dissolution during earlystage dewatering and compaction those aided localised silica precipitation. However, the nature of the silicifying fluid was unknown owing to absence of any geochemical studies. We analysed the oxygen isotope ratios of these chert nodules by laser fluorination technique. The $\Delta^{\prime 17} \mathrm{O}-\delta^{\prime 18} \mathrm{O}$ values suggest that the dissolution of carbonates and void-filling silica equilibrium precipitation was mediated by isotopically modified marine water $\left(\delta^{\prime 18} \mathrm{O}=3 \pm 1 \%\right.$ ) at about $100^{\circ} \mathrm{C}$ that corresponds to a depth of about $4 \mathrm{~km}$ considering modern day geotherm.

We have also carried out high resolution, micron-scale oxygen isotope analysis of the host carbonate by laser assisted in-situ technique. The $\delta^{\prime 18} \mathrm{O}$ values of the carbonates form two distinct cluster with ${ }^{18} \mathrm{O}$ depleted values of $18 \pm 1 \%$ and ${ }^{18} \mathrm{O}$ enriched values of $23 \pm 1 \%$. We infer that the host limestone underwent two step diagenesis, first, the near surface early diagenesis in marine condition (water $\delta^{\prime 18} \mathrm{O}=0 \pm 1 \%$, $25^{\circ} \mathrm{C}$ ). Second, at greater depth where the ${ }^{18} \mathrm{O}$ depleted values were incorporated within the carbonate during carbonate precipitation in equilibrium with the silicifying fluid $\left(\delta^{\prime 18} \mathrm{O}=3 \pm 1 \%\right.$ ) that corresponds to a depth of about $4 \mathrm{~km}$ and $\sim 100^{\circ} \mathrm{C}$. This second stage diagenesis was responsible for the chert nodule formation.

Our results refute the previously proposed early diagenetic origin of the chert nodules from the Bhander limestone. Further, from the micro-analysis of carbonate we propose a $0 \pm 1 \%$ o $\delta^{18} \mathrm{O}$ for the late Precambrian ocean. 